\title{
PENINGKATAN KEMAMPUAN MEMBACA PEMAHAMAN WACANA MATEMATIKA MELALUI MODEL PEMBELAJARAN PENGEMBANGAN BERPIKIR KRITIS DENGAN MENGGUNAKAN STRATEGI SQRQCQ (SURVEY, QUESTIONS, READ, QUESTIONS, COMPUTE, QUESTIONS) DI KELAS 7 SMP PGRI 4 CIMAHI
}

\author{
Latifah \\ IKIP Siliwangi \\ latifah@gmail.com \\ Received: XXXXX X, XXXX; Accepted: XXXXX X, XXXX
}

\begin{abstract}
This research entitled Improving the Reading Ability of Understanding Mathematical Discourse through Critical Thinking Learning Model by using the SQRQCQ Strategy (Survey, Questions, Read, Questions, Compute, Questions) in the 7th grade of PGI 4 Cimahi, the sample in this study was 7C as an experimental class and 7D class as a control class. The problems examined are (1) how is the reading learning profile of 7th grade students of SMP PGRI 4 Cimahi? (2) What is the design of reading learning learning in 7th grade students of SMP PGRI 4 Cimahi (3) how is the learning design of critical thinking skills using the SQRQCQ strategy? (4) the influence of the learning model of developing critical thinking skills using the SQRQCQ Strategy in improving reading skills in understanding mathematical discourse. The method used was quasi-experimental with pretest-posttest group design. Research data is obtained through process and learning outcomes. Process data in the form of learning activities using critical thinking approaches and SQRQCQ strategies. This model is based on the learning model presented by Arend, which is a learning or approach designed to teach students to understand reading well and refer to a specific set of cognitive activities and slowly carry out their own functions. The effect of learning models is to develop critical thinking skills using the SQRQCQ strategy in reading material is an understanding of mathematical discourse obtained through a comparison of the results of the $t$ test between the experimental class and the control class and proof of the hypothesis. Based on the results of statistical tests on the experimental class, it is obtained information that $\mathrm{t}$ count is 10.5 . Meanwhile, $t$ table at a significance level of 0.05 or a confidence level of $95 \%$ and $\mathrm{db}$ (46) of 2.515, which turns out the value of $t$ count (10.5) is greater than $t$ table (2.515). Based on this means that Ho is rejected and $\mathrm{Ha}$ is accepted. In other words, learning with the development of critical thinking skills through the SQRQCQ strategy is effective for improving reading skills in understanding the 7th grade mathematics discourse of SMP PGRI 4 Cimahi.
\end{abstract}

Keywords: reading, critical thinking, discourse

\begin{abstract}
Abstrak
Penelitian ini berjudul Peningkatan Kemampuan membaca Pemahaman Wacana matematika melalui Model Pembelajaran Berpikir Kritis dengan menggunakan Strategi SQRQCQ ( Survey, Questions, Read, Questions, Compute, Questions) di kelas 7 SMP PGRI 4 Cimahi, sampel dalam penelitian ini adalah kelas 7C sebagai kelas eksperimen dan kelas 7D sebagai kelas kontrol. Adapun masalah yg dikaji yaitu (1) bagaimanakah profil pembelajran membaca siswa kelas 7 SMP PGRI 4 Cimahi? (2) Bagaimanakah rancangan pembelajaran pembelajaran membaca siswa kelas 7 SMP PGRI 4 Cimahi.(3) bagaimanakah rancangan pembelajaran kemampuan berpikir kritis dengan menggunakan strategi SQRQCQ? (4) pengaruh model pembelajran pengembangan kemampuan berpikir kritis dengan menggunakan Strategi SQRQCQ dalam meningkatkan kemampuan membaca pemahaman wacana matematika.Metode yg digunakan adalah kuasi eksperimen dengan pretes-postes group design. Data penelitian diperoleh melalui proses dan hasil belajar. Data proses berupa kegiatan belajar dengan menggunakan pendekatan berpikir kritis serta strategi SQRQCQ. Model ini didasarkan pada model pembelajaran yang disampaikan Arend ,yakni suatu pembelajaran atau pendekatan yang dirancang untuk mengajarkan kepada siswa memahami bacaan dengan baik dan mengacu kepada sekumpulan
\end{abstract}


2 Latifah, Peningkatan Kemampuan Membaca Pemahaman Wacana Matematika melalui

Model Pembelajaran Pengembangan Berpikir kritis dengan Menggunakan Strategi

SQRQCQ

kegiatan kognitif tertentu dan secara perlahan melakukan fungsi-fungsinya sendiri.Pengaruh model pembelajaran pengembangan kemampuan berpikir kritis dengan menggunakan strategi SQRQCQ dalam materi membaca pemahaman wacana matematika diperoleh melalui perbandingan hasil uji $t$ antara kelas eksperimen dengan kelas kontrol dan pembuktian hipotesis. Berdasarkan hasil uji statistik pada kelas eksperimen, diperoleh keterangan bahwa t hitung sebesar 10,5. Sementara itu, $t$ tabel pada taraf signifikansi 0,05 atau setingkat kepercayaan 95\% dan db (46) sebesar 2,515, yang ternyata nilai $t$ hitung $(10,5)$ lebih besar dari pada t tabel $(2,515)$. Berdasarkan hal tersebut berarti Ho ditolak dan Ha diterima. Dengan kata lain bahwa pembelajaran dengan pengembangan kemampuan berpikir kritis melalui strategi SQRQCQ efektif untuk meningkatkan kemampuan membaca pemahaman wacana matematika siswa kelas7 SMP PGRI 4 Cimahi.

Kata Kunci: membaca, berpikir kritis, wacana

\section{PENDAHULUAN}

\section{Latar Belakang Masalah Penelitian}

Istilah membaca sering dipakai bukan saja dalam kaitannya dengan kajian disiplin ilmu melainkan juga dipakai oleh orang kebanyakan, seperti dalam ungkapan membaca alam, membaca hati, membaca mimik muka dan lain-lain. Dengan memadukan sudut pandang itu hakikat membaca dapat diklasifikasikan kedalam tiga kelompok pandangan, yakni (a) sebagai intepretasi pengalaman, (b) interpretasi lambang grafis, (c) paduan dari interpretasi pengalaman dan lambang grafis. Membaca merupakan proses merekonstruksi makna dari bahan-bahan cetak. Membaca bukan hanya mengubah lambang menjadi bunyi dan mengubah bunyi menjadi makna, melainkan lebih ke proses pemetikan informasi atau makna sesuai dengan informasi atau makna yang diusung si penulisnya. Dalam hal ini, pembaca berusaha membongkar dan merekam ulang apa yang tersaji dalam teks sesuai dengan sumber penyampaiannya. Kegiatan membaca merupakan sesuatu yang penting untuk dilakukan dalam upaya menyerap segala bentuk pengetahuan, sehingga diperoleh suatu kemampuan yang maksimal. Artinya, dengan kegiatan membaca yang luaslah seseorang dapat memperoleh berbagai pengetahuan. Dengan demikian kegiatan membaca merupakan katalisator yang sangat ampuh untuk mendayagunakan sumber daya manusia Indonesia

Manusia dapat berpikir dengan baik karena ia memiliki bahasa, tanpa bahasa manusia tidak dapat berpikir rumit dan abstrak. Bahasa memungkinkan manusia berpikir secara abstrak, dan objek-objek yang faktual ditransformasikan menjadi simbol-simbol bahasa yang bersifat abstrak. Adanya simbol bahasa yang bersifat abstrak ini, memungkinkan manusia untuk berpikir secara lanjut. Demikian juga bahasa memberikan kemampuan berpikir secara teratur dan sistematis. Transformasi objek faktual menjadi simbol abstrak diwujudkan lewat perbendaharaan kata-kata dan kata-kata ini dirangkaikan oleh tata bahasa untuk mengemukakan suatu jalan pemikiran atau ekspresi peranan. Membaca merupakan bagian dari 
keterampilan berbahasa, yang kegiatannya merupakan menafsirkan lambang-lambang bunyi yang membawa gagasan atau materi yang terdapat dalam tulisan atau wacana. Dengan demikian, membaca dapat digunakan sebagai penggali informasi yang terdapat pada berbagai wacana yang ada.

Wacana matematik adalah teks yang memaparkan materi ajar matematika yang dijabarkan dalam bentuk tulisan. Seorang pelajar SMP, tidak hanya mempelajari Bahasa Indonesia saja tetapi juga mempelajari mata pelajaran-mata pelajaran lain. Di antaranya yaitu mata pelajaran matematika. Keterampilan membaca wacana matematika, sangat diperlukan sebagai bekal untuk menangkap informasi yang terdapat dalam wacana tersebut. Untuk memudahkan siswa dalam memahami wacana matematik diperlukan startegi pembelajaran untuk memudahkan siswa dalam memahami wacana yang disajikan berupa symbol dan angka. Berdasarkan latar belakang masalah maka peneliti merumuskan penelitian sebagai berikut

\section{Rumusan Masalah}

1. Bagaimanakah pembelajaran pengembangan kemampuan berpikir kritis dengan menggunakan strategi SQRQCQ siswa kelas7 SMP PGRI 4 Cimahi?

2. Bagaimanakah pengaruh model pembelajaran pengembangan kemampuan berpikir kritis dengan menggunakan strategi SQRQCQ dalam meningkatkan kemampuan membaca pemahaman wacana matematika di kelas 7 SMP PGRI 4 Cimahi?

\section{Tujuan Penelitian}

Tujuan yang akan dicapai dalam penelitian ini yaitu untuk mendeskripsikan yang berkaitan dengan

1. Rancangan pembelaran kemampuan berpikir kritis dengan menggunakan strategi SQRQCQ dalam pembelajaran membaca pemahaman wacana matematika.

2. Pengaruh model pembelajaran pengembangan kemampuan berpikir kritis dengan menggunakan strategi SQRQCQ dalam materi membaca pemahaman wacana matematika. 
4 Latifah, Peningkatan Kemampuan Membaca Pemahaman Wacana Matematika melalui Model Pembelajaran Pengembangan Berpikir kritis dengan Menggunakan Strategi SQRQCQ

\section{Landasan Teori}

\section{Pengertian Membaca}

Hodgson (dalam Tarigan, 1986) memberikan definisi membaca suatu proses yang dilakukan serta digunakan oleh pembaca untuk memperoleh pesan yang hendak disampaikan oleh penulis melalui media kata-kata atau bahasa tulis. Suatu proses yang menuntut agar kelompok kata yang merupakan suatu kesatuan akan terlibat dalam pandangan sekilas dan agar kata-kata secara individual akan dapat diketahui. Jika hal ini tidak terpenuhi, maka pesan yang tersurat maupun yang tersirat tidak akan dipahami dan proses membaca tidak terlaksana dengan baik.

Membaca merupakan suatu keterampilan yang bersifat apresiatif, rumit dan kompleks. Hal ini disebabkan, adanya berbagai faktor saling berhubungan dan berkoordinasi dalam menunjang terhadap pemahaman bacaan. Dalam proses ini terlibat aspek-aspek berpikir seperti, mengingat, memahami, membandingkan, membedakan, menganalisis, dan mengorganisasi dan saling kerja sama untuk menangkap makna yang terdapat dalam suatu wacana secara utuh dan lengkap. Selain itu, dalam kegiatan ini pun terlibat serangkaian keterampilan lain yang lebih sempit cakupannya. Seorang pembaca dituntut untuk mampu mengenal huruf, tanda baca, dan mengorelasikannya dengan unsur-unsur linguistik yang formal.

\section{Anatomi Pertanyaan Membaca}

Pertanyaan bacaan yang digali dari teks bacaan sebagai tolok-ukur pemahaman (kemampuan kognisi) harus menunjukkan jenjang kemampuan kognisi secara proporsional sesuai dengan perkembangan psikologis pembacanya. Jenjang kognisi itu mengacu pada jenjang kognisi yang dikemukakan oleh Benjamin S. Bloom, yakni jenjang (1) ingatan, (2) pemahaman, (3) penerapan/ aplikasi, (4) analisis, (5) sintesis, dan (6) evaluasi.

Dalam menggali pertanyaan bacaan, konsep jenjang kognisi Bloom menjadi dasar untuk pembuatan pertanyaan bacaan yang berdasar pada anatomi pertanyaan membaca. Dalam membaca, keenam jenjang kognisi Bloom itu berkembang menjadi 7, yang meliputi jenjang (1) ingatan, (2) terjemahan, (3) interpretasi, (4) penerapan/ aplikasi, (5) analisis, (6) sintesis, dan (7) evaluasi. 


\section{Pengertian Membaca Pemahaman}

Suatu wacana bila kita amati terdiri atas rentetan huruf dan tanda baca yang membentuk kata atau kelompok kata. Rentetan kata atau kelompok kata tersebut membentuk suatu kalimat. Kumpulan kalimat membentuk paragraf, dan paragraf membentuk suatu karangan atau wacana yang utuh dan mengandung arti.

Proses memahami wacana berkaitan erat dengan kemampuan membaca pemahaman. Seseorang dapat menangkap isi atau makna yang terkandung dalam suatu wacana apabila ia telah mempunyai kemampuan dalam membaca pemahaman. Untuk mengetahui secara mendalam maksud dari kemampuan membaca pemahaman, terlebih dahulu kita harus mengetahui pengertian memahami, kemampuan, dan membaca pemahaman.

Weiner (1985:243) mengatakan bahwa membaca pemahaman merupakan proses yang rumit yang berlangsung pada diri seorang pembaca. Dikatakan demikian, karena dalam proses tersebut pembaca berupaya untuk mendayagunakan segala kapasitas mental yang dimilikinya untuk memperoreh makna (pemahaman) dari bahan yang dibacanya. perlu kita ketahui, bahwa sebuah pemahamaan akan terjadi bila pembaca memiliki sarana pemahaman seperti mengenal dan memahami kata-kata, kalimat, dan mampu menghubungkan ide-ide yang terdapat dalam bahan bacaan dengan pengetahuan yang telah dimilikinya. Pendapat di atas sejalan dengan Tampubolon (1990:6) yang mengatakan bahwa," Membaca pemahaman merupakan suatu proses yang melibatkan penalaran dan ingatan dalam upaya menemukan dan memahami informasi yang di komunikasikan pengarang”.

Berdasarkan tingkatan-tingkatan membaca pemahaman yang dikemukakan di atas dapat diambil kesimpulan bahwa pada hakikatnya secara garis besar terdapat tiga tingkatan membaca pemahaman, yaitu literal, inferensial, dan ekstrapolasi. Tingkatan literal merupakan kemampuan memahami maksud karangan atau menjelaskan makna yang terkandung dalam suatu teks (tersurat). Tingkatan inferensial yaitu kemampuan membuat kesimpulan tentang organisasi atau ide-ide yang terdapat dalam bacaan, sedangkan ekstrapolasi merupakan kemampuan membuat kesimpulan di luar wacana, kreasi ide-ide, konsep-konsep, serta kesimpulan-kesirnpulan yang lebih jauh dari bacaan atau di luar bacaan.

\section{Wacana}

Istilah wacana berasal dari bahasa sansekerta yang bermakna "ucapan atau tuturan" (LBSS,1983:556). Dalam bahasa Inggris, istilah wacana disebut dengan istilah discourse. Kata itu berasal dari bahasa Yunani discursus yang bermakna 'berlari ke sana ke mari'. wacana dapat 
6 Latifah, Peningkatan Kemampuan Membaca Pemahaman Wacana Matematika melalui

Model Pembelajaran Pengembangan Berpikir kritis dengan Menggunakan Strategi

SQRQCQ

diartikan (1) komunikasi pikiran melalui kata-kata, penuangan gagasan konversi, dan (2) karangan, karya tulis, ceramah khotbah, kuliah (Webster, 1,983:522).

Wacana merupakan peristiwa komunikasi yang terstruktur, dimanifestasikan dalam perilaku linguistik dan membentuk suatu keseluruhan yang padu (uniter), (Edmondson, 1981:4). Perilaku linguistik dimanifestasikan dalam bentuk ujaran yang berkesinambungan, unsur-unsurnya berkaitan erat, dan secara gramatikal teratur rapi (Carlson, 1983 xiii-xiv). oleh karena itu, wacana dapat disebut rekaman kebahasaan yang utuh tentang peristiwa komunikasi. Komunikasi dapat menggunakan bahasa lisan maupun bahasa tulisan. wacana bersifat transaksional jika yang dipentingkan ialah 'isi' komunikasi. Sebaliknya, wacana akan bersifat interaksional jika merupakan komunikasi timbal-balik. acana lisan transaksional berupa pidato, ceramah, tuturan, dakwah, deklamasi, dan lain sebagainya. Wacana lisan yang interaksional dapat berupa percakapan, debat, tanya-jawab (sidang peradilan), dan lain sebagainya. wacana tulisan transaksional berupa instruksi, iklan, surat, cerita, esei, makalah, tesis, dan lain sebagainya. Wacana tulisan yang interaksional berupa polemik, surat-menyurat antara dua orang, dan lain sebagainya Apapun bentuknya, wacana mengasumsikan adanya Penyapa (addressor) dan pesapa ( anddressee). Dalam wacana lisan, penyapa ialah pembicara sedangkan pesapa ialah pendengar. Dalam wacana tulisan penyapa ialah penulis sedangkan Pesapa adalah pembaca (Samsuri, 1988:1).

Berdasarkan konstruksinya, wacana merupakan satuan bahasa terlengkap dan tertinggi di atas kalimat atau klausa dengan koherensi dan kohesi tinggi yang berkesinambungan serta mempunyai awal dan akhir yang nyata dan disampaikan secara lisan atau tulisan (Tarigan, 1982:27). Sebagai unsur teratas dan terlengkap, wacana dapat berbentuk karangan yang utuh (novel, buku, artikel, puisi, dan sebagainya) atau paragraf dengan membawa amanat yang lengkap (Kridalaksana, 2004:179). Wacana merupakan rentetan kalimat yang berkaitan dan menghubungkan proposisi yang satu dengan proposisi yang lain untuk membentuk suatu kesatuan (Moeliono \& Dardjowidjojo, 1988:334) sesuai dengan konteks situasi (Deese, 1984:72).

\section{Model Pembelajaran Berpikir Kritis}

Model pembelajaran pada dasarnya merupakan bentuk pembelajaran yang tergambar dari awal sampai akhir yang disajikan secara khas oleh guru. Dengan kata lain, model pembelajaran merupakan bungkus atau bingkai dari penerapan suatu pendekatan, metode, dan teknik pembelajaran. Joyce (2002:6) mengatakan bahwa model pembelajaran adalah suatu perencanaan atau suatu pola yang digunakan sebagai pedoman dalam merencanakan 
pembelajaran di kelas atau pembelajaran dalam tutorial dan untuk menentukan perangkatperangkat pembelajaran termasuk di dalamnya buku-buku, komputer, kurikulum dan lain-lain. Arend (1997:7) mengatakan bahwa model pembelajaran mengacu pada pendekatan pembelajaran yang akan digunakan, termasuk di dalamnya tujuan-tujuan pengajaran, tahaptahap dalam kegiatan pembelajaran, lingkungan pembelajaran, dan pengelolaan kelas. Hal ini sesuai dengan pendapat Joyce (2002:7) yang mengatakan bahwa"Each model guides us as we design instruction to help students achieve various objectives". Pernyataan ini, menyatakan bahwa setiap model mengarahkan dalam mendesain pembelajaran untuk membantu siswa dengan sedemikian rupa hingga tujuan pembelajaran tercapai.

Sudah tentu penggunaan model sangat dipengaruhi oleh sifat materi yang akan diajarkan, penggunaan model juga dipengaruhi oleh tujuan yang akan dicapai dalam pembelajaran tersebut dan tingkat kemampuan siswa. Dengan demikian model pembelajaran merupakan suatu bentuk rancangan pembelajaran yang dibuat oleh guru, sehingga diharapkan tercapai tujuan pembelajaran yang diharapkan. Gagne dan Briggs dalam Mulyana (2000:28) menyampaikan bahwa model pembelajaran bertujuan menyajikan hubungan konseptual antara hasil belajar yang diharapkan dengan metode atau sejumlah metode mengajar yang tepat. Oleh karena itu, model pembelajaran merupakan bagian terpenting dalam kegiatan pembelajaran atau dengan kata lain, model pembelajaran tidak dapat diabaikan begitu saja.

\section{Berpikir Kritis}

Berpikir kritis adalah suatu aktifitas kognitif yang berkaitan dengan penggunaan nalar. Belajar untuk berpikir kritis berarti menggunakan proses-proses mental, seperti memperhatikan, mengkategorikan, seleksi, dan menilai/memutuskan. Kemampuan dalam berpikir kritis memberikan arahan yang tepat dalam berpikir dan bekerja, dan membantu dalam menentukan keterkaitan sesuatu dengan yang lainnya dengan lebih akurat. Oleh sebab itu kemampuan berpikir kritis sangat dibutuhkan dalam pemecahan masalah / pencarian solusi, dan pengelolaan proyek. Pengembangan kemampuan berpikir kritis merupakan integrasi beberapa bagian pengembangan kemampuan, seperti pengamatan (observasi), analisis, penalaran, penilaian, pengambilan keputusan, dan persuasi. Semakin baik pengembangan kemampuan-kemampuan ini, maka kita akan semakin dapat mengatasi masalahmasalah/proyek komplek dan dengan hasil yang memuaskan.

Berpikir kritis meliputi aktivitas-aktivitas

1) memperhatikan detil secara menyeluruh Identifikasi kecenderungan dan pola, seperti memetakan informasi, identifikasi kesamaan dan ketidaksamaan, dll. 
8 Latifah, Peningkatan Kemampuan Membaca Pemahaman Wacana Matematika melalui Model Pembelajaran Pengembangan Berpikir kritis dengan Menggunakan Strategi SQRQCQ

2) mengulangi pengamatan untuk memastikan tidak ada yang terlewatkan Melihat informasi yang didapat dari berbagai sudut pandang

3) memilih solusi-solusi yang lebih disukai secara obyektif mempertimbangkan dampak dan konsekuensi jangka panjang dari solusi yang dipilih.

\section{Metode Penelitian}

Metode yang digunakan dalam penelitian ini adalah metode kuasi eksperimen dengan desain penelitian " The Randomeized Pretest-Postest Control Group Desain “. Untuk lebih jelasnya

Rancangan Penelitian Kuasi Eksperimen

\begin{tabular}{|l|c|c|c|c|}
\hline $\begin{array}{l}\text { Treatment } \\
\text { Group }\end{array}$ & $\mathrm{R}$ & $\mathrm{O}$ & $\mathrm{X}$ & $\mathrm{O}$ \\
\hline $\begin{array}{l}\text { Control } \\
\text { Group }\end{array}$ & $\mathrm{R}$ & $\mathrm{O}$ & $\mathrm{C}$ & $\mathrm{O}$ \\
\hline
\end{tabular}

(Fraenkel \& Wallen, 2006:274 )

\section{Keterangan:}

$\mathrm{R}=$ Random assignment untuk kelas eksperimen dan kelas control

$\mathrm{O}=$ Pengukuran awal (pretes) kelas eksperimen

$\mathrm{O}=$ Pengukuran akhir $($ postes $)$ kelas eksperimen

$\mathrm{O}=$ Pengukuran awal (pretes) kelas kontrol

$\mathrm{O}=$ Pengukuran akhir ( postes ) kelas kontrol

$\mathrm{X}=$ Perlakuan mengajarkan membaca wacana matematika melalui pengembangan berpikir kritis dengan menggunakan strategi SQRQCQC $=$ Perlakuan mengajarkan membaca wacana matematik melalui pengembangan berpikir kritis dengan model konvensional.

Rancangan ini digunakan untuk menguji keefektifan pembelajaran membaca wacana matematika melalui pengembangan berpikir kritis dengan menggunakan strategi SQRQCQ pada siswa kelas 7 SMP PGRI 4 Cimahi dan sebagai pembanding digunakan kelas kontrol . Prosedur eksperimen yang ditempuh adalah sebagai berikut: Langkah kesatu, menentukan kelas eksperimen dan kelas Kontrol.

Langkah kedua, pelaksanaan pretes untuk kelompok eksperimen dan kelompok Kontrol dengan menggunakan instrument tes hasil belajar membaca pemahaman wacana matematika. 


\section{Rancangan Penelitian}

Sesuai dengan tujuan penelitian serta metode dan teknik penelitian, maka alur penelitian dengan menggunakan strategi SQRQCQ untuk meningkatkan kemampuan siswa dalam memahami wacana Matematika dilaksanakan dengan beberapa tahapan yaitu persiapan, pelaksanaan, dan analisis.

\section{RESULTS AND DISCUSSION}

\section{Pembahasan}

Nilai kritis distribusi t pada taraf kepercayaan 95\% dengan derajat kebebasan $(\mathrm{db})=44$ adalah 2,35 ternyata lebih besar dari pada t hitung yang berarti Ho diterima. Berdasarkan perhitungan uji koefisien signifikansi diperoleh thitung sebesar 0,99 sementara itu, $t$ tabel pada taraf signifikansi 0,05 atau setingkat kepercayaan 95\% dan db (44) sebesar 2,515 ternyata nilai t hitung $(0,99)$ lebih kecil dari pada t tabel $(2,35)$. Berdasarkan hal tersebut berarti Ho diertima dan Ha ditolak. Dengan kata lain, bahwa tidak terdapat perbedaan kemampuan membaca pemahaman wacana matematika siswa kelas 7 SMP PGRI 4 Cimahi dalam pembelajaran yang menggunakan pengembangan kemampuan berpikir kritis melalui strategi konvensional dan pembelajaran yang tidak menggunakan pengembangan kemampuan berpikir kritis melalui strategi SQRQCQ.

Tabel 1. Pretes Postes

\begin{tabular}{|c|c|c|c|c|c|}
\hline \multirow{2}{*}{ No } & \multirow{2}{*}{ Nama } & \multicolumn{2}{|c|}{ Nilai } & \multirow{2}{*}{$\mathrm{d}$} & \multirow{2}{*}{$d^{2}$} \\
\hline & & PRETES & POSTES & & \\
\hline 1 & Asep Krisna & 38.34 & 41.67 & 3.33 & 11.09 \\
\hline 2 & Ayi Sutisna & 31.67 & 30.00 & -1.67 & 2.79 \\
\hline 3 & Bagas Novyan & 38.34 & 33.34 & -5.00 & 25.00 \\
\hline 4 & Dadan Julaika & 36.67 & 45.00 & 8.33 & 69.39 \\
\hline 5 & Dea Sucita & 28.34 & 35.00 & 6.66 & 44.36 \\
\hline 6 & Deri Basuni & 30.00 & 30.00 & 0.00 & 0.00 \\
\hline 7 & Devi Dwi S. & 35.00 & 26.67 & -8.33 & 69.39 \\
\hline 8 & Diani Febby A & 30.00 & 58.34 & 28.34 & 803.16 \\
\hline 9 & Didin Mulyana & 26.67 & 63.34 & 36.67 & 1344.69 \\
\hline 10 & Dwi Komaeroh & 26.67 & 30.00 & 3.33 & 11.09 \\
\hline 11 & Ema Agustriani & 26.67 & 66.67 & 40.00 & 1600.00 \\
\hline
\end{tabular}


10 Latifah, Peningkatan Kemampuan Membaca Pemahaman Wacana Matematika melalui Model Pembelajaran Pengembangan Berpikir kritis dengan Menggunakan Strategi SQRQCQ

12 Eneng Eka W.

13 Eva Rosita Y.

14 Frama Yuda Z.

15 Harri Riardy

16 Irfan Nugraha

17 Lavenia

18 Lucky Oktaviandi

19 Lutphy Salman

20 Maryana

21 Muhamad R.

22 Nandang Targana

23 Nani Nuraeni

24 Neni Haryati

25 Nira Triani

26 Noorlina Desiani

27 Nur Afni H.R.

28 Pini Gusliana

29 Pipit Fitria

30 Ramdhan Anjas S.

31 Regina Fitri P.

32 Rika Ramdiani

33 Rini Ariani

34 Rizki Nugraha

35 Sanny Setiawan

36 Sari Amelia

37 Siti Noor Faujiah

38 Siti Patimah

39 Sri Linati Rani R.

40 Tessa Lelawati

41 Tika Aprianti

42 Yeni Triana

\begin{tabular}{|c|c|c|c|}
\hline 31.67 & 40.00 & 8.33 & 69.39 \\
\hline 28.34 & 35.00 & 6.66 & 44.36 \\
\hline 36.67 & 38.34 & 1.67 & 2.79 \\
\hline 38.34 & 58.34 & 20.00 & 400.00 \\
\hline 36.67 & 48.34 & 11.67 & 136.19 \\
\hline 28.34 & 30.00 & 1.66 & 2.76 \\
\hline 26.67 & 53.34 & 26.67 & 711.29 \\
\hline 36.67 & 45.00 & 8.33 & 69.39 \\
\hline 31.67 & 33.34 & 1.67 & 2.79 \\
\hline 36.67 & 56.67 & 20.00 & 400.00 \\
\hline 26.67 & 33.34 & 6.67 & 44.49 \\
\hline 25.00 & 71.67 & 46.67 & 2178.09 \\
\hline 25.00 & 78.34 & 53.34 & 2845.16 \\
\hline 26.67 & 78.34 & 51.67 & 2669.79 \\
\hline 30.00 & 70.00 & 40.00 & 1600.00 \\
\hline 26.67 & 76.67 & 50.00 & 2500.00 \\
\hline 26.67 & 68.34 & 41.67 & 1736.39 \\
\hline 26.67 & 25.00 & -1.67 & 2.79 \\
\hline 26.67 & 73.34 & 46.67 & 2178.09 \\
\hline 28.34 & 31.67 & 3.33 & 11.09 \\
\hline 33.34 & 31.67 & -1.67 & 2.79 \\
\hline 25.00 & 38.34 & 13.34 & 177.96 \\
\hline 31.67 & 36.67 & 5.00 & 25.00 \\
\hline 35.00 & 56.67 & 21.67 & 469.59 \\
\hline 25.00 & 30.00 & 5.00 & 25.00 \\
\hline 25.00 & 48.34 & 23.34 & 544.76 \\
\hline 25.00 & 68.34 & 43.34 & 1878.36 \\
\hline 26.67 & 71.67 & 45.00 & 2025.00 \\
\hline 23.34 & 31.67 & 8.33 & 69.39 \\
\hline 25.00 & 33.34 & 8.34 & 69.56 \\
\hline 25.00 & 68.34 & 43.34 & 1878.36 \\
\hline
\end{tabular}




\begin{tabular}{llcccc}
43 & Vika Melani & 33.34 & 31.67 & -1.67 & 2.79 \\
44 & Wanda Rusli F. & 38.34 & 28.34 & -10.00 & 100.00 \\
\hline & Jumlah & 1320.00 & 2080.00 & 760.00 & 577600.00 \\
& Rata-rata & 30.00 & 47.27 & 17.27 & 298.35
\end{tabular}

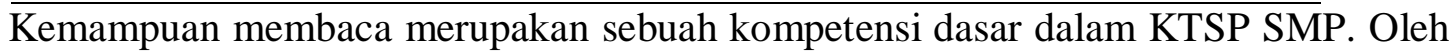
karena itu, kemampuan membaca perlu diajarkan sebaik mungkin melalui pembelajaran. Penggunaan teknik SQRQCQ ini memudahkan pembelajar dalam meningkatkan membacanya. Di samping itu, teknik SQRQCQ dalam membaca juga mengaktifkan siswa dalam mengembangkan kemampuan berpikir kritis dalam memahami sebuah wacana.

Realisasi pembelajaran kemampuan membaca dengan teknik SQRQCQ terikat dua hal, yaitu (1) keseluruhan proses pembelajaran berorientasi pada kebermaknaan dan (2) pembelajaran berorientasi kepada pembelajar. Pola-pola pembelajaran kemampuan membaca dapat bervariasi. Menurut Tampubolon (1990:16) mata memainkan peranan sangat penting dalam membaca dan membaca. Peranan yang dimaksud ialah otak menerima stimulus dari bacaan dan merumuskannya ke otak untuk diproses di dalam penulisan. Dalam hal ini dua aspek pokok yang perlu diperhatikan, yaitu stimulus dan gerakan mata. Berdasrkan uraian di atas, dapat dinyatakan bahwa ada dua kemampuan yang harus diperhatikan dalam membaca, yaitu kemampuan visual dan kemampuan berpikir atau bernalar.

Di dalam meningkatkan kemampuan membaca siswa, perlu diperhatikan orientasi pembelajarannya. Salah satu orientasi pembelajaran yang diterapkan di dalam penelitian ini adalah dengan orientasi pendekatan pembelajaran dengan teknik SQRQCQ.

Siswa memiliki kemampuan membaca yang rendah karena salah satu faktor penyebabnya adalah guru kurang melatih mereka dalam memadukan keterampilan membaca dengan keterampilan berbahasa lain, yaitu keterampilan membaca, menyimak, dan berbicara. Di dalam teknik SQRQCQ untuk kemampuan membaca, penulis menggabungkan beberapa tahapan membaca yang sistematis ini. Dalam pembelajaran yang dilakukan ditekankan materi pembelajaran membaca dengan pengembangan topik dan pemberian tugas-tugas pada setiap materi tertentu. Melalui penggunaan teknik SQRQCQ, siswa akan termotivasi untuk berlatih membaca dengan rajin sebab setiap langkah SQRQCQ merangsang siswa untuk berpikir.

Perencanan pembelajaran pengembangan kemampuan berpikir kritis dengan menggunakan strategi SQRQCQ dalam meningkatkan kemampuan membaca pemahaman 
12 Latifah, Peningkatan Kemampuan Membaca Pemahaman Wacana Matematika melalui

Model Pembelajaran Pengembangan Berpikir kritis dengan Menggunakan Strategi

SQRQCQ

wacana matematika di kelas 7 SMP PGRI 4 Cimahi dirumuskan melalui skenario pembelajaran berikut ini.

1) Kegiatan Pembuka- Apersepsi

(a) siswa menyimak penjelasan guru mengenai tujuan dan langkah pembelajaran yang akan dilaksanakan;

(b) guru membagi kelompok diskusi, pemilihan ketua serta penulisnya, kemudian membagikan lembar kerja siswa yang berfungsi sebagai panduan pembelajaran; dan

(c) guru mengajak siswa untuk bertanya jawab tentang hal-hal yang menyangkut membaca, manfaat membaca, dan konsep-konsep lain yang terkait dengan membaca.

2) Kegiatan Inti

(a) guru mengadakan tanya jawab tentang materi yang disampaikan dan menghubungkannya dengan pengetahuan yang sudah dipahami siswa;

(b) berdasarkan teks yang telah ditentukan sebelumnya, siswa membaca teks secara intensif;

(c) siswa merumuskan beberapa pertanyaan tentang isi teks, pertanyaan disusun untuk mengarahkan kegiatan membaca.

(d) Guru meminta salah seorang siswa untuk menguraikan hasil bacaannya di depan kelas dengan kata-kata sendiri;

(e) guru meminta siswa yang lainnya memberikan tanggapan mengenai uraian tersebut; dan

(f) guru mengadakan tanya jawab tentang isi teks dan tanggapan-tanggapan siswa.

3) Kegiatan Penutup

(a) Siswa membahas kembali strategi menemukan kalimat utama pada tiap paragraf dengan membaca intensif melalui teknik SQRQCQ ;

(b) Siswa dan guru mengadakan refleksi dan membahas hasil pekerjaan siswa untuk menemukan kekurangan-kekurangannya.

(c) Guru menutup pelajaran.

Hasil penerapan model pembelajaran pengembangan kemampuan berpikir kritis dengan menggunakan strategi SQRQCQ dalam meningkatkan kemampuan membaca pemahaman wacana matematika di kelas 7 C SMP PGRI 4 Cimahi mengalami peningkatan. Berdasarkan 
hasil pretes diperoleh angka 33,83 sedangkan hasil postes 64,24. Selisih tersebut menunjukkan adanya kenaikan keampuan siswa sebesar 25,91 atau 40,33\%.

Pada kelas pembanding atau kelas kontrol. Hasil penerapan model konvensional (jigsaw) dalam meningkatkan kemampuan membaca pemahaman wacana matematika di kelas 7 D SMP PGRI 4 Cimahi mengalami peningkatan. Berdasarkan hasil pretes diperoleh 30,00 sedangkan hasil postes 47,27. Selisih tersebut menunjukkan adanya kenaikan keampuan siswa sebesar 17,27 atau $27,39 \%$.

Dengan demikian, penelitian ini menolak $H_{0}$ pertama, yakni tidak terdapat perbedaan kemampuan membaca pemahaman wacana matematika siswa kelas 7 SMP PGRI 4 Cimahi dalam pembelajaran yang menggunakan pengembangan kemampuan berpikir kritis melalui strategi PQRST dan pembelajaran yang tidak menggunakan pengembangan kemampuan berpikir kritis melalui strategi SQRQCQ. Dengan kata lain, penelitian ini menerima $H_{i}$ yakni terdapat perbedaan kemampuan berpikir kritis siswa kelas 7 SMP PGRI 4 Cimahi dalam membaca wacana matematik antara pembelajaran yang menggunakan pengembangan kemampuan berpikir kritis melalui strategi SQRQCQ dan pembelajaran yang tidak menggunakan pengembangan kemampuan berpikir kritis melalui strategi SQRQCQ.

Di samping itu, penelitian ini pun menolak hipotesis $H_{0}$ kedua yakni pembelajaran dengan pengembangan kemampuan berpikir kritis melalui strategi SQRQCQ tidak efektif untuk meningkatkan kemampuan membaca pemahaman wacana matematika siswa kelas7 SMP PGRI 4 Cimahi. Dengan $\mathrm{k}$ ata lain, penelitian ini pun menerima $H_{i}$ kedua, yakni pembelajaran dengan pengembangan kemampuan berpikir kritis melaluistrategi SQRQCQ efektif untuk meningkatkan kemampuan membaca pemahaman wacana matematika siswa kelas7 SMP PGRI 4 Cimahi.

\section{SIMPULAN DAN SARAN}

\section{Simpulan}

Latar belakang penelitian ini adalah harapan bahwa kreativitas guru-guru dalam mengajar akan berkembang dengan tersedianya model-model pembelajaran yang efektif dan variatif. Untuk memenuhi harapan tersebut, peneliti mengangkat suatu permasalahan yang difokuskan kepada pembelajaran bahasa Indonesia di SMP, yakni penerapan model pembelajaran 
14 Latifah, Peningkatan Kemampuan Membaca Pemahaman Wacana Matematika melalui

Model Pembelajaran Pengembangan Berpikir kritis dengan Menggunakan Strategi

SQRQCQ

pengembangan kemampuan berpikir kritis dengan menggunakan strategi SQRQCQ dalam meningkatkan kemampuan membaca pemahaman wacana matematika di kelas 7 SMP PGRI 4 Cimahi.

Model pembelajaran pengembangan kemampuan berpikir kritis dengan menggunakan strategi SQRQCQ dalam meningkatkan kemampuan membaca pemahaman wacana matematika berangkat dari asumsi bahwa membaca merupakan suatu proses dalam memahami pikiran penulis yang dituangkannya dalam bacaan. Untuk dapat memahami sebuah teks, pembaca harus mampu memberdayakan kapasitas berpikirnya dengan optimal. Sedangkan keterampilan berpikir kritis berangkat dari asumsi bahwa keterampilan berpikir kritis merupakan suatu proses tingkah laku dalam menentukan pemikirannya.

Berdasarkan hasil penilitian diperoleh beberapa simpulan sebagai berikut

1. Profil kemampuan membaca pemahaman mengalami peningkatan setelahdiberikan perlakuan baik proses maupun hasil setelah menggunakan strategi SQRQCQ.

2. Kualitas pembelajaran pengembangan kemampuan berpikir kritis menggunakan strategi SQRQCQ dalam materi membaca pemahaman wacana matematika diperoleh melalui data hasil observasi terhadap aktivitas guru dan siswa pada saat proses pembelajaran berlangsung. Simpulan hasil observasi terhadap guru menyatakan bahwa aktivitas guru pada saat mengadakan pembelajaran pengembangan kemampuan berpikir kritis dengan menggunakan strategi SQRQCQ dalam meningkatkan kemampuan membaca pemahaman wacana matematika di kelas 7 SMP PGRI 4 Cimahi pembelajaran baik menuju sangat baik. Demikian pula halnya pada hasil observasi terhadap aktivitas siswa pada saat mengikuti proses pembelajaran. Simpulannya bahwa lebih dari setengah jumlah siswa atau $56,52 \%$ beraktivitas sangat baik pada saat mengikuti pembelajaran.

3. Hasil belajar siswa dalam membaca wacana matematik melalui pengembangan kemampuan berpikir kritis dengan menggunakan strategi SQRQCQ mengalami kenaikan yang signifikan. Perolehan rata-rata nilai pretes 38,33 sedangkan rata-rata nilai postes 64,24. Jadi terdapat kenaikan sebesar 25,91 atau 40,33\%. Hasil kenaikan yang siginifikan secara kuantitatif tersebut pun ditunjukkan pula oleh hasil observasi dan penilaian guru yang pada umumnya menunjukkan sangat baik dan baik.

4. Pengaruh model pembelajaran pengembangan kemampuan berpikir kritis dengan menggunakan strategi SQRQCQ dalam materi membaca pemahaman wacana matematika diperoleh melalui perbandingan hasil uji t antara kelas eksperimen dengan 
kelas kontrol dan pembuktian hipotesis. Berdasarkan hasil uji statistik pada kelas eksperimen, diperoleh keterangan bahwa t hitung sebesar 10,5. Sementara itu, $t$ tabel pada taraf signifikansi 0,05 atau setingkat kepercayaan 95\% dan db (46) sebesar 2,515, yang ternyata nilai t hitung $(10,5)$ lebih besar dari pada $t$ tabel $(2,515)$. Berdasarkan hal tersebut berarti Ho ditolak dan Ha diterima. Dengan kata lain bahwa pembelajaran dengan pengembangan kemampuan berpikir kritis melalui strategi SQRQCQ efektif untuk meningkatkan kemampuan membaca pemahaman wacana matematika siswa kelas7 SMP PGRI 4 Cimahi. Hal ini berbanding terbalik pada kelas kontrol. Berdasarkan perhitungan uji koefisien signifikansi diperoleh t hitung sebesar 0,99 sementara itu, $\mathrm{t}$ tabel pada taraf signifikansi 0,05 atau setingkat kepercayaan 95\% dan $\mathrm{db}(44)$ sebesar 2,515. Ternyata nilai t hitung $(0,99)$ lebih kecil dari pada t tabel $(2,35)$. Berdasarkan hal tersebut berarti Ho diterima dan Ha ditolak. Dengan kata lain, bahwa terdapat perbedaan kemampuan membaca pemahaman wacana matematika siswa kelas 7 SMP PGRI 4 Cimahi dalam pembelajaran yang menggunakan pengembangan kemampuan berpikir kritis melalui strategi Campuran (ceramah,diskusi dan tanya jawab), dan pembelajaran yang tidak menggunakan pengembangan kemampuan berpikir kritis melalui strategi SQRQCQ.

\section{Saran-saran}

Berdasarkan temuan-temuan dalam penelitian ini, ada beberapa saran yang perlu dikemukakan. Saran-saran tersebut adalah sebagai berikut.

1) Model pembelajaran pengembangan kemampuan berpikir kritis dengan menggunakan strategi SQRQCQ dalam materi membaca pemahaman wacana matematika perlu dikembangkan terus sebagai salah satu model pembelajaran membaca di SMP karena sudah terbukti berpengaruh terhadap keterampilan membaca wacana siswa.

2) Perlu mencermati langkah-langkah strategi SQRQCQ dengan kritis karena sangat menentukan keberhasilan dalam melaksanakan model pembelajaran pengembangan kemampuan berpikir kritis dengan menggunakan strategi SQRQCQ dalam materi membaca pemahaman wacana matematika sehingga menambah wawasan pengetahuan sebagai sarana kreativitas dalam mengelola kegiatan pembelajaran membaca.

3) Instrumen pengukuran keterampilan membaca kritis terdiri dari soal-soal pilihan ganda dan essay terbuka yang dikembangkan sendiri dalam penelitian ini, belum 
16 Latifah, Peningkatan Kemampuan Membaca Pemahaman Wacana Matematika melalui Model Pembelajaran Pengembangan Berpikir kritis dengan Menggunakan Strategi SQRQCQ

diparalelkan dengan soal-soal yang disusun oleh pihak lain. Artinya peneliti belum menemukan formula khusus untuk mengukur keterampilan itu berdasarkan pertimbangan tersebut. Oleh karena itu, perlu diadakan penelitian lain yang sejenis yang menggunakan soal-soal bentuk lain sebagai alternatif dari soal-soal sebelumnya.

4) Hasil penelitian penerapan model pembelajaran pengembangan kemampuan berpikir kritis dengan menggunakan strategi SQRQCQ dalam materi membaca pemahaman wacana matematika, menyatakan bahwa model tersebut mampu mengembangkan keterampilan berpikir kritis siswa terutama di SMP, maka peneliti merekomendasikan agar guru-guru bahasa Indonesia menerapkan model pembelajaran pengembangan kemampuan berpikir kritis dengan menggunakan strategi SQRQCQ dalam materi membaca pemahaman wacana matematika.

5) Hasil penelitian ini, merupakan model pembelajaran dalam membaca pemahaman. Oleh karena itu, hasil penelitian ini dapat dijadikan rujukan untuk penelitian-penelitian lanjutan baik pada wacana yang sama, maupun wacana-wacana lainnya.

\section{REFERENCES}

Bachman, Edmund. (2005). Metode Belajar Berpikir Kritis dan Inovatif. Jakarta: PT Prestasi Pustakaraya

Nurhadi. (2008). Membaca Cepat dan Efektif. Bandung: Sinar Baru Algensindo.

Resnick B. Lauren. (1987). Educational and Learning To Think. National Academy Press. Washingto, D.C.

Silberman, Melvin L. (2006). Active Learning 101 Cara Belajar Siswa Aktif. Bandung: Nusamedia.

Soedarso. (2001). Sistem Membaca Cepat dan Efektif. Jakarta : Gramedia

Stone, Randi. (2009). Cara-cara Terbaik Mengajarkan Matematika. Jakarta : Indeks

Sudjianto. (1995). Kemampuan Berbahasa Indonesia. Jakarta : Depdikbud.

Sugiyono. (2005). Statistika untuk Penelitian. Bandung: ALFABETA.

Suhendar, M.E. \& Supinah, P. (1992). Pengajaran dan Ujian Keterampilan Membaca dan Keterampilan Menulis MKDU Bahasa Indonesia ). Jakarta : Depdikbud

Tampibolon, D.P. (1990). Kemampuan Membaca, Teknik Membaca Efektif dan Efisien. Bandung : angkasa.

Tarigan, H.G. (1990). Membaca dalam kehidupan. Bandung : Angkasa.. 
Trianto. (2007). Model-model Pembelajaran Inovatif Berorientasi Konstruktivistik. Jakarta Prestasi Pustaka

Wiryodijoyo, S. (1989). Membaca, Strategi, Pengantar dan Tekniknya. Jakarta : Depdikbud. 